\title{
Selection, Identification and Optimization of the Growth Water Probiotic Consortium of Mangrove Ecosystems as Bioremediation and Biocontrol in Shrimp Ponds
}

\author{
Wilis Ari Setyati ${ }^{*}$, Erni Martani ${ }^{2}$, Triyanto ${ }^{2}$, Subagiyo ${ }^{3}$, Muhammad Zainuddin ${ }^{4}$ \\ 1) Departement of Marine Science, Faculty of Fisheries and Marine Science \\ Diponegoro University, Post-graduate Student, Gadjah Mada University \\ 2)Departement of Biotechnology, Post-graduate, Gadjah Mada University. \\ $\left.{ }^{3}\right)$ Marine Science Laboratory, Marine Science Departement, Diponegoro University. \\ ${ }^{4}$ )Natural Product Laboratory, UPT (Integrated Laboratory), Diponegoro University. \\ Faculty of Fisheries and Marine - Tembalang - Semarang Telp 0247474698 \\ *Coresponding author: wilisarisetyati@yahoo.co.id
}

Accepted April 15 ${ }^{\text {th }}, 2014 /$ Approved Agustus 10 $0^{\text {th }}, 2014$

\begin{abstract}
Shrimp aquaculture is an activity that potentially generates organic waste. The accumulation of organic matter is becoming one of the main factors causing the emergence of disease. Problem-solving approach that is most effective is through bioremediation. The aims of this study were to select, identify and cultivate bacteria from mangrove sediments from Cilacap, Rembang and Banyuwangi which potentially as probiotic consortium of bioremediation activity and biocontrol. The results showed that total of 45 isolates (proteolytic), 35 isolates (amylolytic), 35 isolates (lipolytic), and 18 isolates (cellulolytic). There were 59 bacterial isolates had antibacterial activity of vibrio (V. harveyi, V. alginolyticus, V. vulnificus and V. anguilarum). Based on the identification of 16 S-rRNA genes, 4 isolates showed that the C2 isolate was identified as Bacillus subtilis, C11 isolate was identified as Bacillus firmus, C13 and C14 isolates were identified as B. Flexus. This study concluded that cultivation of Bacillus subtilis $\mathrm{C} 2$ optimum at $2 \%$ molase and yeast extract $0.5 \%$ at $\mathrm{pH} 8$ and 30 0C. Bacillus firmus $\mathrm{C} 11$ optimum at $2 \%$ molase and yeast extract $0.5 \%$ at $\mathrm{pH} 8$ and $300 \mathrm{C}$. Bacillus flexus $\mathrm{C} 13$ optimum at $2 \%$ glucose and yeast extract $0.5 \%$ at $\mathrm{pH} 8$ and $300 \mathrm{C}$. Bacillus flexus $\mathrm{C} 14$ optimum at $4 \%$ molase and yeast extract $0.25 \%$ at $\mathrm{pH} 8$ and $300 \mathrm{C}$. The result of culture applications of 4 isolates showed an effect of increasing shrimp weight by $141,9 \%$ compared by the control.
\end{abstract}

Keywords: sediment, mangrove, bioremediation, biocontrol

\section{Introduction}

Shrimp farm produces organic waste from the residue of the shrimp feed and feces. Jackson's studies (2003) showed that the nitrogen efficiency usage offeed was approximately $22 \%$, whereas $78 \%$ of nitrogen was discharged into the environment and accumulated in the bottom of sediment pond. High organic matters content will spur on the growth of microorganisms, biodecomposition process and oxygen consumption (Avnimelech and Ritvo 2003). Insufficient oxygen conditions triggers the growth of anaerobic microorganisms which actively reducing $\mathrm{SO}_{4}^{2-}$ into $\mathrm{H}_{2} \mathrm{~S}$ that inhibited the growth of domestic animals (Mugnier et al. 2008). It is necessary to attempt to overcome the accumulation of organic matter in the sediment pond. The most effective approach is through bioremediation (microorganism's agent). Organic waste of feed are complex, so that, bioremediation requires a consortium of different microorganisms with the kind of variation of activity to clean up organic matter.

In addition to environmental stress factors, the problems are encountered in the development of shrimp farming is a factor of disease (Smith and Briggs 1993). So that the developing water probiotic consortium should have the function to clean the organic material (biodecomposition) while controling the pathogen population (biocontrol). Therefor, to produce probiotic bacteria it is necessary to screen, optimization of growth mediums and probiotic application test. 


\section{Materials and Methods}

The study was conducted by the laboratory experimental method and design of complete randomized study. Overall, the study will be carried in 5 stages: isolations, selections, identifications, cultivations and applications. Insulating phase consists of the preparation, dilution and purification. Selection phase consists of selection of proteolytic activity, amylolytic, cellulolytic, lipolytic, antibacterial and antaginis. Phase of identification of the molecular basis of bacterial consortium-based on 16S rRNA gene. Cultivation phase of probiotic consortium consists of 4 phases: screening and selecting of probiotic growth nutrients, optimization the nutrient concentrations of growth, optimization the $\mathrm{pH}$ growth, and optimization the growth temperature. Consortium Application phase was conducted on a bench scale (bench scale).

\section{Isolation of Bacteria}

Sediment sampling was performed on mangrove area in Cilacap, Rembang and Banyuwangi. Sediment samples were taken using a soil sampler at a depth of $+10 \mathrm{~cm}$. The Sediment samples were diluted up to 10-5, 10-6 and 10-7, respectively inoculation performed by pour plate method. Furthermore petri dishes were incubated for $2 \times 24$ hours. The colonies of bacteri which were formed on each petri dish from each dilution were isolated that showed different morphology. Isolation and purification of bacterial isolates were performed by the method of scratches (streak method).

\section{Bacteria Based Selection Capability Doing Biodegradation of Organic Materials}

Screening will be done for bacteria that are capable of altering or degrading polysaccharides, proteins and fats by the approaching the activity of protease enzymes, amylase, cellulase and lipase. Tests were carried out by the procedure of proteolytic activity by Jacob \& Gerstein (1960) within Bairagi et al. (2002) by using 2216 E Zobell medium enriched with skim milk (1\%).

Amylolytic activity test was carried out by the procedure according to Jacob \& Gerstein (1960) in Bairagi et al. (2002) which used 2216 E Zobell agar medium enriched with starch (1\%). Lugol's iodine solution is poured above $1 \%$ of bacteria for agar identification of amylolytic activity (clear zone was formed). Cellulolytic activity test was performed using agar medium enriched with $1 \%$ CMC. Congo red solution was poured into the bacteria for identification of cellulose hydrolysis activity. Lipolytic activity test was done according to the procedure Sangiliyi and Gunasekeran (1996) in Bairagi et al. (2002) which used 2216 E Zobel agar medium enriched with 80 tween. Lipase activity was shown by the formation of fatty acid deposits around the bacteria.

\section{Bacterial Selection Based on Antibacterial Capability}

Antibacterial test for all isolates against pathogens $(V$. alginoliticus, $V$. harveyi, $V$. anguilarum and $V$. vulnivicus ) were performed by puncturing technique and overlaying (Isnansetyo 2004). the pure isolate cultures were inserted on the 2216 E Zobell agar medium by using a needle preparation and were incubated for 24 hours. After 24 hours of incubation, the overlay was done by pouring the pathogen into Zobell $2216 \mathrm{E}$ soft agar medium (70\%). Double layered then were incubated for 24 hours. Antagonist activity was identified by the production of clear zone without growth (inhibition zone) around the puncture of colony.

\section{Antagonist Test Between Isolates}

Antagonist tests were conducted using streak on Zobell agar medium. Antagonist activity was shown by the clear zone/barrier zone around the colony.

\section{Identification of Bacteria Consortium by 16s-rrna Gene Molecular}

The amplification of 16S-rRNA gene was performed by using $1 \mathrm{~mL}$ of DNA template were amplified by PCR Beadskit RTG using a universal primer (Marchesi et al. 1998), there were 63F 
(5'-CAGGCCTAACACATGCAAGTC) and 1387r (5'-GGGCGGWGTGTACAAGGC). It was made a master mix containing 1.5 units of Tag DNA polymerase, $10 \mathrm{mM}$ Tris $\mathrm{HCl}(\mathrm{pH}$ 9.0 at room temperature), $50 \mathrm{mM} \mathrm{KCl}, 1.5 \mathrm{mM}$ $\mathrm{MgCl} 2,200 \mathrm{mM}$ on each dNTP and a stabilizer and including BSA and $1 \mathrm{~mL}$ of DNA template. Then, put into a PCR machine, GeneAmp PCR Systems 2400 (Perkin Elmer Biosystems, USA), with the Pre-PCR conditions $\left(94^{\circ} \mathrm{C}, 2\right.$ minutes), denaturation $\left(92^{\circ} \mathrm{C}, 30\right.$ seconds), primer annealing $\left(55^{\circ} \mathrm{C}, 30\right.$ seconds ), elongation $\left(75^{\circ} \mathrm{C}, 1 \mathrm{~min}\right)$ and a Post PCR $\left(75^{\circ} \mathrm{C}, 5 \mathrm{~min}\right)$, the cycle 30 times. The results of 16S-rRNA gene amplification which produced the positif results were followed on positive sequencing analysis. Homology analysis was done by online at http:// www.ddbj.nig.ac.jp/.

\section{Screening and Selecting of Nutrient Growth}

The methods used in this study followed the procedure according to Polak-Bereka et al. (2010) and Sathyanarayanan et al. (2011). Three carbon sources is glucose, fructose, and molasses, also three nitrogen sources peptone, yeast extract and urea at a concentration of $1 \%$ will be screened according to the production of biomass. All of the media were adjusted to $\mathrm{pH}$ 6.0. Medium were inoculated by starter isolates that gave $\mathrm{OD} 0.01$ on the $\mathrm{A}_{600}$. Incubation at room temperature, every 6 hours for 30 hours intervals, samples were taken as many as $4 \mathrm{~mL}$ then measuring the $\mathrm{OD}$ at $\mathrm{A}_{600}$.

\section{Screening and Selecting of Nutrient}

Three concentrations of carbon sources were $1 \%, 2 \%$ and $4 \%$, and three concentrations of nitrogen sources were $0.25 \%, 0.5 \%$ and $1.0 \%$. Medium was inoculated with starter isolates that gave OD 0.01 on the A600. Incubation at room temperature and at intervals of 6 hours for 30 hours samples were taken at $7 \mathrm{~mL}$. then it were measured for the OD at A600 and the dry weight of the bacteria.

\section{Optimizing of $\mathrm{pH}$}

Medium with carbon sources and nitrogen sources with the optimum concentration was adjusted to $\mathrm{pH}$ variation of 6,7 and 8 then were inoculated with a starter isolates that gave $\mathrm{OD} 0.01$ on $\mathrm{A}_{600}$ and incubation at room temperature. Each 12-hour intervals for 60 hours samples were taken by $10 \mathrm{~mL}$, then measuring the $\mathrm{OD}$ at $\mathrm{A}_{600}$.

\section{Optimizing of Temperature}

Medium was added with a carbon sources and a nitrogen sources at the optimum concentration. It were inoculated with a starter isolates that gave OD 0.01 on the $\mathrm{A}_{600}$. Incubation at varied temperature 30 , 34 and $380 \mathrm{C}$. every 12-hour intervals for 60 hours samples were taken by $7 \mathrm{~mL}$ then were performed measuring $\mathrm{OD}$ at $\mathrm{A}_{600}$.

\section{Tests of Consortium Application}

The application consortium tests at the laboratory scale using a plastic tub, sea water and soil sediment pond which was dried at a thickness about $10 \mathrm{~cm}$. Each test basins used aeration system and the shrimps (tokolan) were spreaded at a density of 12 shrimps tails / 50 liters of water. Feeding was done 3 times a day with the amount of $5 \%$ of the total weight of shrimp were stocked. Observations were carried on growth, water quality (ammonia, nitrite and nitrate), and the total population of bacteria (TPC). This observing were done for 15 days.

\section{Analysis of Data}

All data were obtained then analyzed using descriptive and analytical one way ANOVA with Tukey's test $p=0.05$ level.

\section{Results and Discussion}

The isolation and selection of heterotrophic bacteria that are capable of producing proteolytic enzymes (proteases), amylolytic (amylase), lipolytic (lipase) and cellulolytic (cellulose), as well as test results of antibacterial activity against 4 types of bacteria vibrio ( $V$. harveyi, V. alginolyticus, V. vulnificus $V$. anguilarum) was shown in Figure 1. 


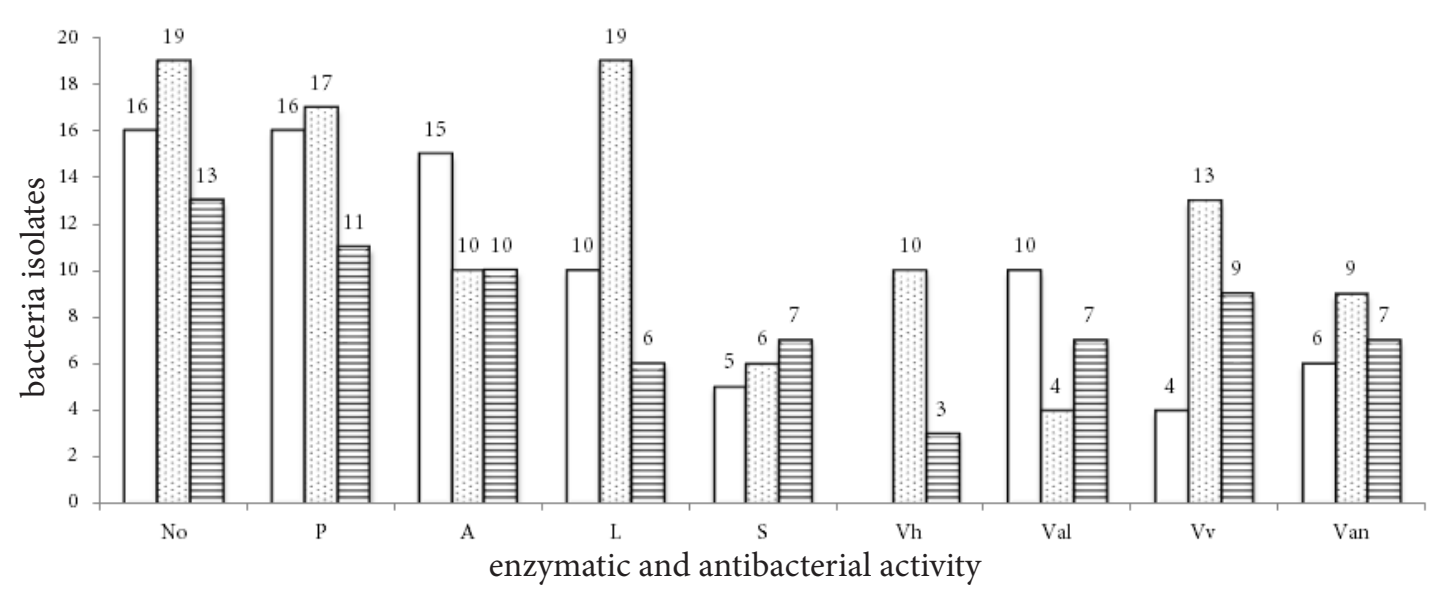

Note: No: Number of isolates; P: Proteolytic, A: Amilolytic, L: Lipolytic, S: Selulolytic, Vh: V. harveyi, Val: V. alginolyticus, Vv: V. vulnificus, Van: V. anguilarum. Rembang, Cilacap, Banyuwangi

Figure 1 The number of isolates bacteria which have enzymatic and antibacterial activity

The results of Antagonist activity test among isolates obtained 9 isolates that produced extracellular enzymes and 5 isolates which actively inhibiting bacteria vibrio that each other were not antagonistic. Based on the capabilities of multi activities which are non-antagonistic to each other were obtained total of 4 potential isolates to be developed as a consortium, C-02, C- $11, \mathrm{C}-13$ and $\mathrm{C}$-14. Some researchers showed that bacteria heterotrophic in mangrove ecosystem was the main source of extracellular enzymes that was necessary for mineralization of organic material which produces enzymes including amylases, proteases, esterases and lipases (Dias et al. 2009).

The results based on the identification of 16 S-rRNA genes indicated that the C-02 isolates were identified as Bacillus subtilis. C-11 isolates were identified as Bacillus firmus and isolates C-13 and C-14 were identified as Bacillus flexus. Bacteria were gram-positive bacillus, rod-shaped, endospores form was resistant to high temperature, low temperature, radiation, drying and disinfectants, aerobic or facultative anaerobic (Turnbull, 1996). Bacteria of the genus Bacillus has been widely used and developed as an agent to decompose organic material and pathogen control. The capability of Bacillus bacteria to produce antibacterial compounds were carried out by Vaseeharan and Ramaswamy (2003) who tested the BT application of Bacillus subtilis 23 to control vibrio bacteria in shrimp farming.

The result of the selection of carbon and nitrogen sources for the production of probiotic bacteria was shown in Table 1 and Table 2. Based on the analysis of the growth rate (Table 1) showed that the C2 Bacillus subtilis, Bacillus firmus C11, and Bacillus

Table 1 The growth rate of probiotic bacteria on different carbon source media treatment

\begin{tabular}{lccc}
\hline \multirow{2}{*}{ Isolates } & \multicolumn{3}{c}{ Growth Rate of Bacteria (OD/hours) } \\
\cline { 2 - 4 } & Fructose & Glucose & Molase \\
\hline Bacillus subtilis C2 & $0.037 \pm 0.0014^{\mathrm{a}}$ & $0.047 \pm 0.0063^{\mathrm{b}}$ & $0.050 \pm 0.0048^{\mathrm{b}}$ \\
Bacillus firmus C11 & $0.040 \pm 0.0013^{\mathrm{a}}$ & $0.049 \pm 0.0057^{\mathrm{b}}$ & $0.052 \pm 0.0052^{\mathrm{b}}$ \\
Bacillus flexus C13 & $0.014 \pm 0.0017^{\mathrm{a}}$ & $0.049 \pm 0.0010^{\mathrm{c}}$ & $0.046 \pm 0.0008^{\mathrm{b}}$ \\
Bacillus flexus C14 & $0.043 \pm 0.0091^{\mathrm{a}}$ & $0,046 \pm 0.0076^{\mathrm{a}}$ & $0.053 \pm 0.0063^{\mathrm{a}}$ \\
\hline
\end{tabular}

Note: The average of \pm standard deviation, Italic letters on the same value in the same row are not significantly different at $p>0.05$. 
Table 2 The growth rate of probiotic bacteria on different nitrogen source media treatment

\begin{tabular}{lccc}
\hline \multirow{2}{*}{\multicolumn{1}{c}{ Isolates }} & \multicolumn{2}{c}{ Growth Rate of Bacteria (OD/hours) } \\
\cline { 2 - 4 } & Pepton & Yeast extract & Urea \\
\hline Bacillus subtilis C2 & $0.018 \pm 0.0018^{\mathrm{b}}$ & $0.024 \pm 0.0020 \mathrm{c}^{\mathrm{c}}$ & $0.005 \pm 0.0003^{\mathrm{a}}$ \\
Bacillus firmus C11 & $0.032 \pm 0.0021^{\mathrm{b}}$ & $0.036 \pm 0.0080^{\mathrm{b}}$ & $0.013 \pm 0.0033^{\mathrm{a}}$ \\
Bacillus flexus C13 & $0.033 \pm 0.0075^{\mathrm{b}}$ & $0.045 \pm 0.0010^{\mathrm{c}}$ & $0.017 \pm 0.0035^{\mathrm{a}}$ \\
Bacillus flexus C14 & $0.025 \pm 0.0018^{\mathrm{a}}$ & $0,041 \pm 0.0053^{\mathrm{b}}$ & $0.022 \pm 0.0014^{\mathrm{a}}$ \\
\hline
\end{tabular}

Note: The average of \pm standard deviation, Italic letters on the same value in the same row are not significantly different at $p>0.05$.

Table 3 The growth of probiotic bacteria on optimized carbon sources media treatment

\begin{tabular}{lcccc}
\hline \multirow{2}{*}{ Isolates } & \multirow{2}{*}{ Nutrition } & \multicolumn{3}{c}{ Growth Rate of Bacteria (OD/hours) } \\
\cline { 3 - 5 } & & $1 \%$ & $2 \%$ & $4 \%$ \\
\hline Bacillus subtilis C2 & Molase & $0.0171 \pm 0.0024^{\mathrm{a}}$ & $0.0341 \pm 0.0043^{\mathrm{c}}$ & $0.0313 \pm 0.0088^{\mathrm{b}}$ \\
Bacillus firmus C11 & Molase & $0.0154 \pm 0.0013^{\mathrm{a}}$ & $0.0218 \pm 0.0044^{\mathrm{b}}$ & $0.0142 \pm 0.0002^{\mathrm{a}}$ \\
Bacillus flexus C13 & Glucose & $0.0141 \pm 0.0001^{\mathrm{a}}$ & $0.0312 \pm 0.0010^{\mathrm{b}}$ & $0.0252 \pm 0.0002^{\mathrm{b}}$ \\
Bacillus flexus C14 & Molase & $0.0189 \pm 0.0002^{\mathrm{a}}$ & $0,0284 \pm 0.0041^{\mathrm{b}}$ & $0.0324 \pm 0.0067^{\mathrm{b}}$ \\
\hline $\begin{array}{l}\text { Note: The average of } \pm \text { standard deviation, Italic letters on the same value in the same row } \\
\text { are not significantly different at } p>0.05 .\end{array}$
\end{tabular}

flexus $\mathrm{C} 14$ have a high growth rate on $1 \%$ molasses respectively the rate of change in $\mathrm{OD} /$ hour at $0,050 \pm 0,0048^{\mathrm{b}}, 0.052 \pm 0,0052^{\mathrm{b}}$, and $0.053 \pm 0,0063^{\text {a }}$. While Bacillus flexus $\mathrm{C} 13$ had the highest growth rate at addition of $1 \%$ glucose is $0.049 \pm 0,0010^{c}$.

The high growth in Zobell liquid medium which was enriched with molasses was occurred due to the molasses as carbon source as well as sources of minor vitamin and nutrients that can be used as a growth factor (Kulpreecha et al. 2005). The low capability of Bacillus flexus $\mathrm{C} 13$ to use molasses indicated that C13 strains had different physiological characteristics, primarily related to the ability to produce extracellular enzymes which was needed to break down complex organic carbon such as molasses. Glucose is a simple sugar that is available to be directly used for bacteria.

Based on the analysis of growth rate (Table 2) showed that the best source of nitrogen as a co-substrate to increase the growth rate of those 4 bacteria was yeast extract. It might be possible because of yeast extract had advantages over other nitrogen sources. It was In line with research PeighamyAshnaei et al. (2007) that yeast extract was

Table 4 The growth of probiotic bacteria on optimized nitrogen sources media treatment

\begin{tabular}{lccc}
\hline \multirow{2}{*}{ Isolates } & \multicolumn{3}{c}{ Concentration of Yeast Source at pH 8} \\
\cline { 2 - 4 } & $0.25 \%$ & $0.5 \%$ & $1 \%$ \\
\hline Bacillus subtilis C2 & $0.0300 \pm 0.0087^{\mathrm{b}}$ & $0.0368 \pm 0.0004^{\mathrm{b}}$ & $0.0061 \pm 0.0004^{\mathrm{b}}$ \\
Bacillus firmus C11 & $0.0162 \pm 0.0033^{\mathrm{a}}$ & $0.0256 \pm 0.0001^{\mathrm{b}}$ & $0.0153 \pm 0.0020^{\mathrm{b}}$ \\
Bacillus flexus C13 & $0.0232 \pm 0.0037^{\mathrm{a}}$ & $0.0294 \pm 0.0023^{\mathrm{b}}$ & $0.0204 \pm 0.0020^{\mathrm{a}}$ \\
Bacillus flexus C14 & $0.0344 \pm 0.0010^{\mathrm{b}}$ & $0,0230 \pm 0.0055^{\mathrm{a}}$ & $0.0242 \pm 0.0018^{\mathrm{a}}$ \\
\hline
\end{tabular}

Note: The average of \pm standard deviation, Italic letters on the same value in the same row are not significantly different at $p>0.05$. 
Table 5 The growth of probiotic bacteria on optimum carbon sources and $\mathrm{pH}$ with temparature media treatment

\begin{tabular}{lccc}
\hline \multirow{2}{*}{ Isolates } & \multicolumn{3}{c}{ Carbon Source with a Temeprature $\left({ }^{\circ} \mathrm{C}\right)$} \\
\cline { 2 - 4 } & 30 & 34 & 38 \\
\hline Bacillus subtilis C2 & $0.2898 \pm 0.0055^{\mathrm{c}}$ & $0.2350 \pm 0.0018^{\mathrm{a}}$ & $0.2630 \pm 0.0026^{\mathrm{b}}$ \\
Bacillus firmus C11 & $0.2148 \pm 0.0010^{\mathrm{c}}$ & $0.1878 \pm 0.0019^{\mathrm{b}}$ & $0.1694 \pm 0.0018^{\mathrm{a}}$ \\
Bacillus flexus C13 & $0.2937 \pm 0.0055^{\mathrm{c}}$ & $0.2820 \pm 0.0026^{\mathrm{a}}$ & $0.2223 \pm 0.0018^{\mathrm{b}}$ \\
Bacillus flexus C14 & $0.4157 \pm 0.0016^{\mathrm{c}}$ & $0,2537 \pm 0.0021^{\mathrm{a}}$ & $0.3925 \pm 0.0049^{\mathrm{b}}$ \\
\hline
\end{tabular}

Note: The average of \pm standard deviation, Italic letters on the same value in the same row are not significantly different at $p>0.05$.

a good source of nitrogen for the growth of most Bacillus subtilis compared with urea and malt extract (Figure 2).

Based on the results of carbon source screening, that followed by optimization of concentration (Table 3). Results of optimization of the concentration of carbon source (glucose and molasses) showed that the optimum concentration of glucose were added to cultures of Bacillus flexus $\mathrm{C} 13$ was the concentration of $2 \%$, whereas the optimum concentration of molasses which were added to the culture C2 Bacillus subtilis, and Bacillus firmus C11 were $2 \%$, and Bacillus flexus C14 was $4 \%$ (Figure 3 ).
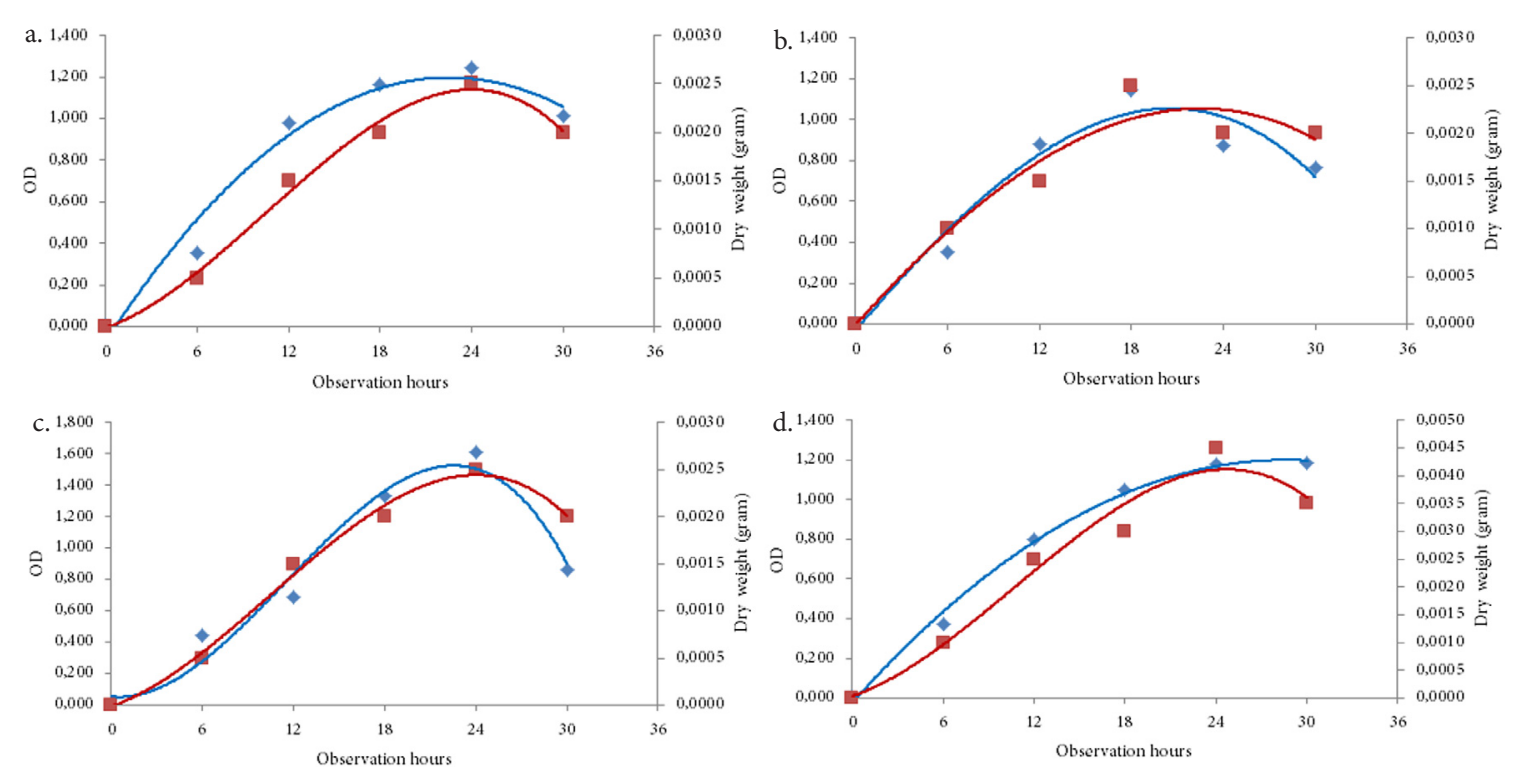

The results above indicated that different bacterial strains had an optimum concentration for different source (molasses). The results of the study Magdi et al. (2010) obtained different results with this research that molasses concentration optimal for growth of Bacillus subtilis $\mathrm{KO}$ was $10 \%$. This suggests that different bacterial strains had an optimum concentration for different. C source (molasses).

Based on the results of nitrogen source screening, that followed by optimization of nitrogen source concentration. The Results of optimization of the concentration of the nitrogen source (yeast extract) (Table 4)

Note: A. Bacillus subtilis C2, Yeast 0,5\% pH 8. B. Bacillus firmus C11, Yeast 0,5\% pH 8. C. Bacillus flexus C13, Yeast 0,5\% pH 8. D. Bacillus flexus C14, Yeast 0,25\% pH 8 .

Figure 2 OD and Dry weight of bacteria on optimum nitrogen sources concentration media 

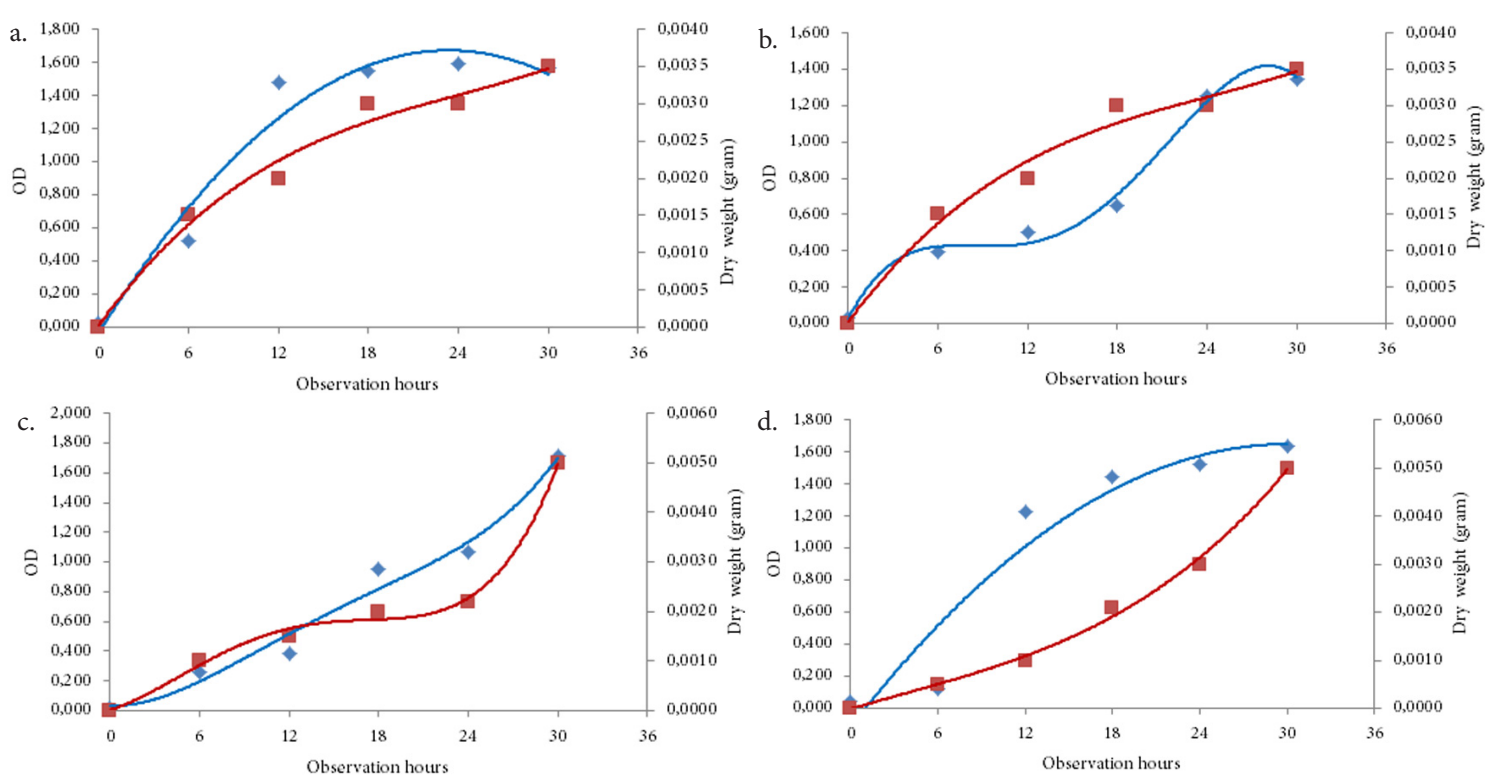

Note: A. Bacillus subtilis C2, Molase 2\% pH 8. B. Bacillus firmus C11, Molase 2\% pH 8. C. Bacillus flexus C13, Glucose 2\% pH 8. D. Bacillus flexus C14, Molase 4\% pH 8.

OD,

: Dry Weight (gram).

Figure $3 \mathrm{OD}$ and dry weight of bacteria on optimum carbon source concentration media

were occurred at a concentration of $0.5 \%$ except Bacillus flexus C14 was occurred at a concentration of $0.25 \%$.

The results of the study Magdi et al. (2010) obtained different results with this research that molasses concentration optimal for growth of Bacillus subtilis KO was10\%.

Based on the $\mathrm{pH}$ optimization results obtained optimum $\mathrm{pH}$ for the growth of all four types of bacteria on Zobell liquid medium with the addition of a source of $\mathrm{C}$ and $\mathrm{N}$ at the optimal concentration was 8 (Figure 4 and 5). It indicated that all four types of bacteria were classified to bacteria alkalophilic.

Alkalophilic Bacteria were microorganisms that lived well at alkaline $\mathrm{pH}$ (above $\mathrm{pH} 7$ ). Results of research conducted by Magdi et al. (2010) in Bacillus subtilis KO obtained optimum $\mathrm{pH}$ of $6.5-7 \mathrm{pH}$. The Optimization results for Bacillus firmus was carried out by Roosdiana et al. (2013) that obtained an optimum $\mathrm{pH}$ value of 7-8. $\mathrm{pH}$, it was in line with the results of this research.

Other environmental factor that greatly affects the rate of bacterial growth was temperature. Temperature had effect on the stability of the functional molecular structure especially the enzyme. Enzyme was catalysts of metabolic reactions. Results of optimization of cultivation temperature for the four types of bacteria in Zobell liquid medium with the addition of a carbon source (molasses and

Table 6 The growth of probiotic bacteria on optimum nitrogen sources and $\mathrm{pH}$ media with temparature optimization treatment

\begin{tabular}{lccc}
\hline \multirow{2}{*}{ Isolates } & \multicolumn{3}{c}{ Carbon Source with a Temeprature $\left({ }^{\circ} \mathrm{C}\right)$} \\
\cline { 2 - 4 } & 30 & 34 & 38 \\
\hline Bacillus subtilis C2 & $0.2868 \pm 0.0028^{\mathrm{c}}$ & $0.0917 \pm 0.0013^{\mathrm{a}}$ & $0.1918 \pm 0.0011^{\mathrm{b}}$ \\
Bacillus firmus C11 & $0.2025 \pm 0.0019^{\mathrm{c}}$ & $0.1676 \pm 0.0039^{\mathrm{b}}$ & $0.1216 \pm 0.0012^{\mathrm{a}}$ \\
Bacillus flexus C13 & $0.2480 \pm 0.0044^{\mathrm{b}}$ & $0.2375 \pm 0.0017^{\mathrm{a}}$ & $0.3120 \pm 0.0016^{\mathrm{b}}$ \\
Bacillus flexus C14 & $0.3806 \pm 0.0012^{\mathrm{c}}$ & $0,2014 \pm 0.0014^{\mathrm{a}}$ & $0.2615 \pm 0.0068^{\mathrm{b}}$ \\
\hline
\end{tabular}

Note: The average of \pm standard deviation, Italic letters on the same value in the same row are not significantly different at $p>0.05$. 

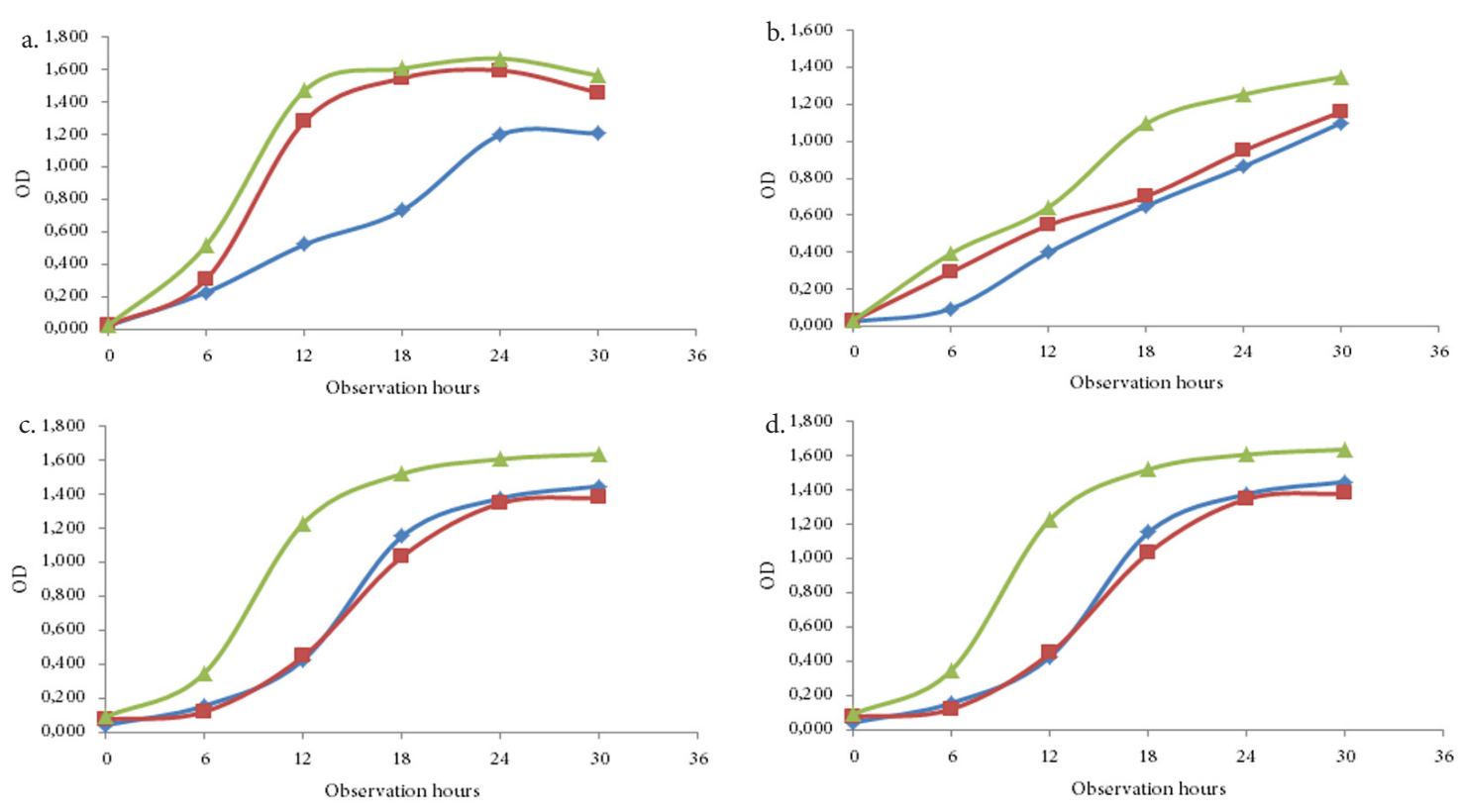

Note: A. Bacillus subtilis C2, Molase 2\%. B. Bacillus firmus C11, Molase 2\%. C. Bacillus flexus C13, Glucose 2\%. D. Bacillus flexus C14, Molase 4\%. $-\longrightarrow: \mathrm{pH} 6,--: \mathrm{pH} 7,-\mathbf{A}-$ : $\mathrm{pH} 8$

Figure $4 \mathrm{OD}$ bacteria at optimum carbon source media optimization ph treatment
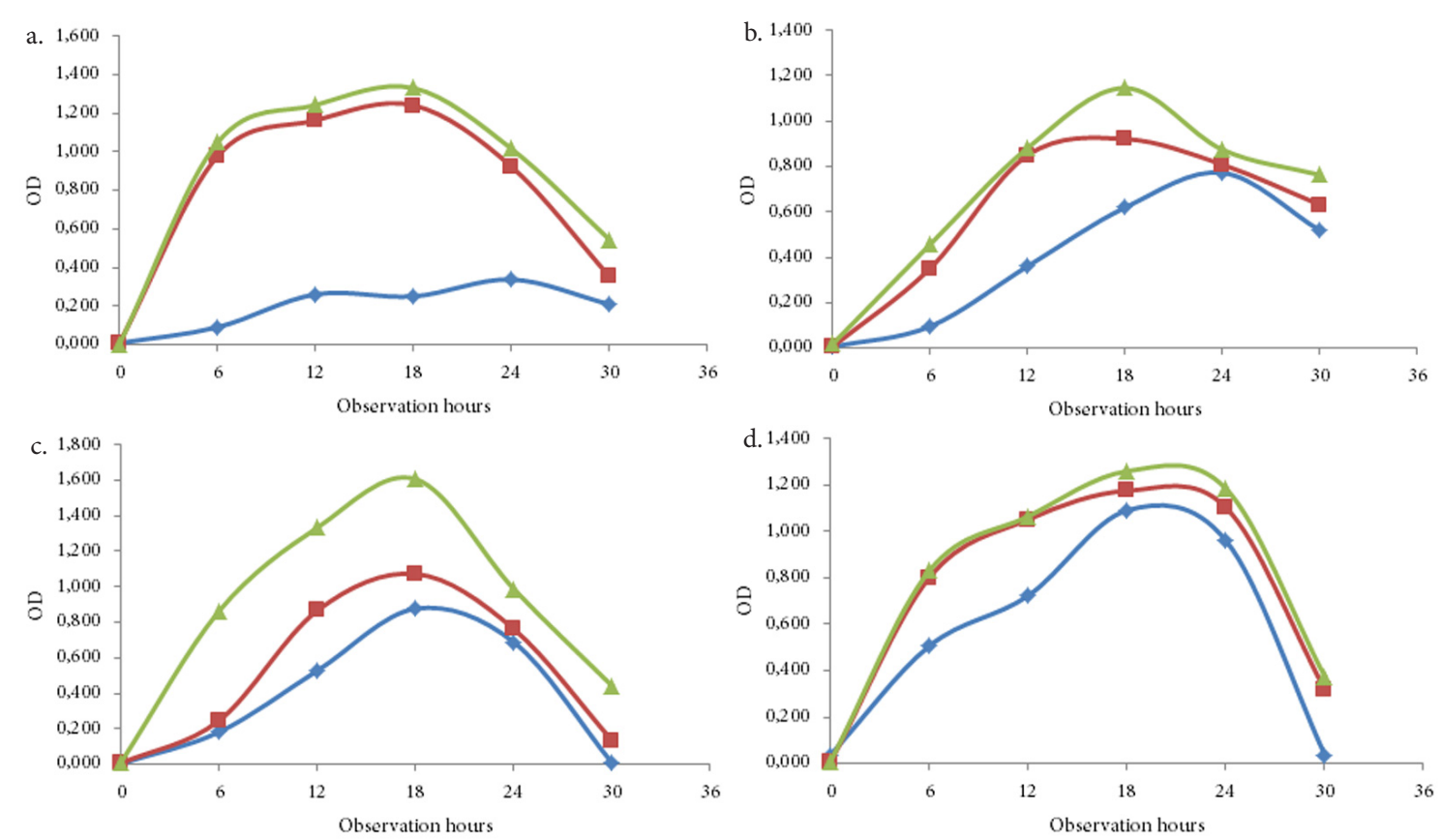

Note: A. Bacillus subtilis C2, Yeast 0.5\%. B. Bacillus firmus C11, Yeast 0.5\%. C. Bacillus flexus C13, Yeast 0.5\%. D. Bacillus flexus C14, Yeast 0.25\%. — $-\mathrm{pH} 6,--: \mathrm{pH} 7,-\underline{\mathrm{A}}-\mathrm{pH} 8$

Figure 5 OD bacteria at optimum nitrogen source media optimization ph treatment

glucose) and nitrogen source (yeast extract) were shown in Table 5 and Table 6.

The result of the growth analysis showed that all four types of bacteria grew optimally at $30^{\circ} \mathrm{C}$. Bacteria that lived optimally at $30^{\circ} \mathrm{C}$ including mesophilic bacteria group. Mesophilic microorganisms were microorganisms that grew in the temperature in range $20-30^{\circ} \mathrm{C}$. The different results obtained in the study Falguni and Sharma 

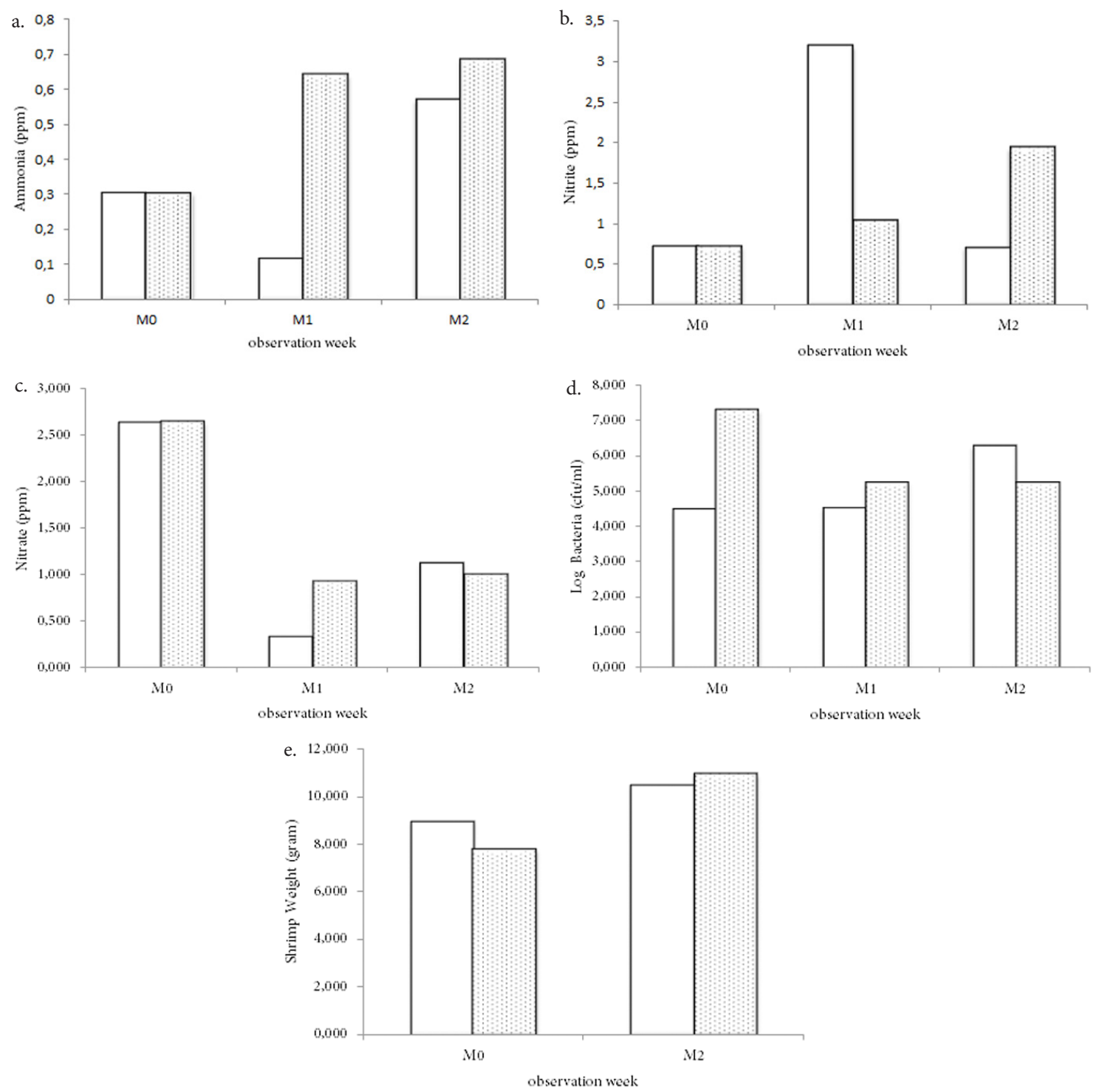

Note: Concentrations of ammonia (a.), nitrite (b.), nitrate (c.), total bacteria in water medium (d.) and shrimp weight (e.) with probiotic applications treatment. M0, 1, 2 : observation week 0, 1, 2. Control, $\square$ Probiotic

Figure 6 Analysis of ammonia, nitrite, nitrate and total bacteria in Water Medium with Probiotic Applications Treatment

(2012) that the optimum temperature for growth of Bacillus flexus FPB 17 was $35^{\circ} \mathrm{C}$. The difference in the optimum temperature for Bacillus firmus might occur due to different strains.

The results of analysis of ammonia, nitrite, nitrate and total bacteria in Water Medium with Probiotic Applications Treatment were shown in Figure 6. The Results showed an increase of ammonia during the research. Ammonia is a product of nitrification of nitrogenous organic material by bacteria and excretion activity by shrimps. According Hovanec and De Long (1996), the types of nitrifying bacteria include: the group of ammonia-oxidizing bacteria that consisting of Nitrosomonas europaea, Nitrosococcus mobilis, Nitrosolobus multiformis; The group of nitrite-oxidizing bacteria consisted Nitrobacter winogradskyi, Nitrobacter agilis, Nitrococcus mobilis. The pattern changes of ammonia, nitrite and nitrate in this tests 
showed that the high nitrification process on treatment, the oxidation process from ammonia to nitrite was low and the process of oxidation from nitrite to nitrate was high.

Probiotic consortium application showed the changes of microbiological community. Isolates 13 and isolates 14 were isolates that having antagonistic activity against Vibrio bacteria. So the existence of these two isolates causing changes bacteriological community. This change brought a positive effect on shrimp growth. This was indicated by the effect of increasing the weight of shrimp in the application of probiotic, which caused an increase compared to the control. Antagonistic activity by consortium members against pathogenic bacteria, especially bacteria vibrio might be possible to control the presence of harmful bacteria.

\section{Conclusion}

The results of this study showed a total of 44 isolates having proteolytic activity, 35 isolates had amylolytic activity, 35 isolates had lipolytic activity, and 18 isolates had cellulolytic activity of, 12 isolates of nitrifying bacteria, and 59 isolates of bacteria that have antagonistic activity against Vibrio bacteria. The results of this study concluded that there were 4 selected isolates from selection of bacteria isolates. Bacillus subtilis C-02, C- 11 , Bacillus firmus, Bacillus flexus C-13 and C-14 Bacillus flexus were potential to be developed as consortium of probiotic for shrimp farming because of their non-antagonostic to each other. Cultivation of Bacillus subtilis C2 and Bacillus firmus C11 reached an optimum at $2 \%$ carbon molase sources and yeast extract nitrogen sources $0.5 \%$ at $\mathrm{pH} 8$ and temperature $30^{\circ} \mathrm{C}$. Bacillus flexus $\mathrm{C} 13$ had optimum at $2 \%$ glucose carbon sources and yeast extract nitrogen sources $0.5 \%$ at $\mathrm{pH} 8$ and temperature $300^{\circ} \mathrm{C}$. Bacillus flexus $\mathrm{C} 14$ had optimum at $4 \%$ molasses carbon sources and yeast extract nitrogen sources $0.25 \%$ at $\mathrm{pH}$ 8 and temperature $30^{\circ} \mathrm{C}$. The result of culture applications of these 4 isolates showed an effect of increasing shrimp weight achieved by the control. Water quality analysis indicated levels of ammonia, nitrite and nitrate tended to be higher in the treatment than in the control.

\section{References}

Avnimelech Y, and G. Ritvo. 2003. Shrimp and fish pond soils: processes and management. Aquaculture 220:549-567.

Atlas, RM. Bartha, R. (1998): Microbial Ecology, Fundamental and Applications. The Benjamin/Cumming Publ. Co. California.

Bairagi A, Ghosh K, Kumarsen S, Ray A K. 2002. Enzyme producing bacterial flora isolated from fish digestive tracts. Aquaculture International 10 : 109-121.

Dias ACF, Andreote FD, Dini-Andreote F, Lacava PT, Sa ALB, Melo IS, Azevedo JL, Arau' jo WL. 2009. Diversity and biotechnological potential of culturable bacteria from Brazilian mangrove sediment. World Journal Microbiol Biotechnology 25:1305-1311.

Falguni PR, and Sharma MC. 2012. Optimizatio of Production of Alkali Phosphatase by a Facultative Alkaliphile Bacillus flexus FPB 17 Isolated from Alkaline Lake Soils. Journal of Agriculture Technology 8(5):1605-1612.

HovanecTA, andDeLongEF. 1996. Comparative Analysis of Nitrifying Bacteria Associated with Freshwater and Marine Aquaria. Applied and Environmental Microbiology 62(8):2888-2896.

Isnansetyo A. 2004. Bakteri Antagonis sebagai Probiotik Untuk Pengendalian Hayati Pada Akuakultur. Jurnal Perikanan 1: 1-10. Isnansetyo A. 2004. Uji Antagonistik Langsung, Suatu Metode Baru Skrining Bakteri Penghasil Antibiotik dan Penerapannya Untuk Skrining Probiotik. Prosiding Seminar Nasional Penyakit Ikan dan Udang, Univeritas Jendral Soedirman, Purwokerto.

Jakcson C, Preston N, Thompson PJ, Burford M. 2003.: Nitrogen Budget and Efluent Nitrogen Components at an Intensive 
Shrimp Farm. Aquaculture 218:397-411.

Kulpreecha S, Boonruangthavorn A, Meksiriporn B, and Thongchul N. 2009. Inexpensive fed-batch cultivation for high poly (3-hydroxybutyrate) production by a new isolate of Bacillus megaterium. Journal of Bioscience and Bioengineering 107(3):240-245.

Magdi AMY, Francis FH, Moustafa AN and Mohamed SAS. 2010. Optimization of Cultivation Medium and Growth Conditions for Bacillus subtilis KO Strain Isolated from Sugar Cane Molasses. America-Eurasian Journal Agriculture of Environment Science 7(1):31-37.

Mugnier C, Zipper E, Goartant C, and Lemonnier H. 2008. Combined effect of exposure to ammonia and hypoxia on the blue shrimp Litopenaeus stylirostris survival and physiological response in relation to molt stage. Aquaculture 274:398-40.

Peighamy-Ashnaei S, Sharifi-Tehrani A, Ahmadzadeh M, and Behboudi K. 2007. Effect of carbon and nitrogen sources on growth and biological efficacy of Pseudomonas fluorescens and Bacillus subtilis against Rhizoctonia solani, the causal agent of bean damping-off. Commun, Agriculture Applied Biology Science 72(4):951-6.

Roosdiana A, Prasetya S, Mahdi C, Sutrisno. 2013. Production and Characterization of Bacillus firmus Pectinase. Journal Pure Applied Chemistry Resource 2(1):35-41.

Smith D, Davey S. 1993. Evidence for The Competitive Exclusion of Aeromonas salmenicida From Fish With StressInducible Furrunculosis by A Flourescent Pseudomonas. Journal of Fish Deseases 16:521-524.

Turnbull PCB. 1996. Bacillus, Medical Microbiology. 4th edition. Baron S, editor., Galveston (TX): University of Texas Medical Branch at Galveston.

Vaseeharan B, Ramasamy P. 2003. Control of pathogenic Vibrio spp. by Bacillus subtilis BT23, a possible probiotic treatment for black tiger shrimp Penaeus monodon. Lett Applied Microbiology 36(2):83-7. 